\title{
O Movimento Estudantil de Medicina e a transformação da Escola Médica
}

A luta do Movimento Estudantil de Medicina (MEM) para a transformação da escola médica é antiga e já teve diferentes alicerces conceituais. Hoje, imbricada em um movimento pela transformação da educação médica, assume novos contornos e se realiza em diversos espaços cada vez mais amplos dos concebidos inicialmente. Se traçarmos um paralelo a partir do movimento estudantil podemos perceber como foi o envolvimento cada vez maior de diversos atores que se somaram a um processo que ainda se amplia e que caminha a passos largos para a hegemonia.

Desde muito o MEM coloca como tema de reflexão-atuação privilegiado a transformação da educação médica. Esta transformação sempre foi pensada no sentido de adequar-se às necessidades sociais $e$ à construção de um sistema de saúde integral, com controle socia $e$ acesso universal, gratuito e orientado para responder à luta pela qualidade de vida da sociedade.

Na década de oitenta, mais especificamente após 86 (ano de criação da Direção Executiva Nacional dos Estudantes de Medicina, DENEM), o MEM fez uma opção clara de se qualificar tecnicamente sobre o tema, educação médica, a fim de acumular poder para pressionar um movimento de transformação da escola médica. Havia uma
Hêider A. Pinto ${ }^{1}$

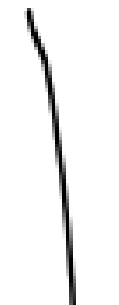

certa resistência, por parte de alguns grupos, em aceitar a necessidade de aprofundamento teórico sobre o tema como sendo papel do movimento estudantil. Esses grupos defendiam que o MEM deveria ser um ator de pressão social e não formulador de projetos e modelos, muito combativo e pouco propositivo, além de não considerarem estratégica uma luta setorial dentro de um projeto de transformação maior da sociedade.

Nos primeiros anos da DENEM os Encontros Científicos dos Estudantes de Medicina (ECEM's) foram espaços importantes de envolvimento dos estudantes na discussão sobre o sistema de saúde vigente, do modelo hegemônico das escolas médicas e da relação $e$ falta de integração entre estes dois. Em dois anos de sucessivos encontros da DENEM, foram problematizados temas e construídas propostas alternativas aos mesmos, sendo formulada a Proposta de Transformação do Ensino Médico (PTEM), aprovada por unanimidade em um ECEM.

Munidos de uma proposta alternativa, os CA's e DA's de Medicina de todo o país pautam esta discussão nas escolas e forçam uma tomada de posição dos outros atores que compõem este espaço: professores $e$ funcionários técnico-administrativos. A

\footnotetext{
${ }^{1}$ Aluno do sétimo período do curso de Medicina da Universidade do Pernambuco; Coordenador Geral da Direção Executiva Nacional dos Estudantes de Medicina, DENEM/Movimento em Defesa da Vida. <heiderap@hotmail.com>
} 
capacidade de envolvimento de estudantes em torno desta luta foi maior do que o inicialmente esperado. Isto pode ser explicado, entre outras razões, pelo fato de este debate manter uma imbricada conexão entre uma luta social mais geral $e$ o cotidiano de todos os estudantes (todos vivenciam, têm entendimentos, anseios $e$ angústias em relação ao tema).

Entretanto, a capacidade de envolvimento dos estudantes que não militavam na DENEM mostrou ter limites. $\mathrm{O}$ movimento cresceu, porém não o suficiente para propiciar uma correlação de forças que tensionasse e impulsionasse a transformação. Apesar da DENEM contar com uma estrutura democrática horizontalizada em que as demandas que orientam as ações da entidade são levantadas pelos próprios estudantes, nas avaliações constatou-se que a agenda do estudante não militante era diferente da agenda prioritária do movimento. Esta agenda em grande parte era pautada pela escola, daí surgindo uma constatação fundamental da DENEM no início da década de noventa: além de responder a tantas outras necessidades, a transformação da escola médica era também fundamental para o próprio fortalecimento da DENEM. A escola médica e a sociedade trabalham, geram e circulam insuficientemente valores como solidariedade, eqüidade, justiça, liberdade, democracia, crítica, esperança, auto-estima, entre tantos outros, fundamentais para a valorização $e o$ engajamento do estudante no movimento estudantil. Entender a escola médica como importante espaço-processo de formação dos indivíduos - construtor de referências, significados e valores, gerador de demandas e produtor de modos de subjetivação - foi fundamental para explicar a força com que a DENEM entrou na luta para a almejada "revolução" da educação e escola médica.

$\mathrm{Na}$ década de noventa, com outra estrutura e já atendendo pelo título "movimento em defesa da vida", a DENEM compreende que para que fosse desencadeado um processo legítimo, sólido, qualificado e efetivo de transformação deveria haver um envolvimento, no debate $e$ na construção, de toda a comunidade acadêmica. Era preciso que este projeto fosse do coletivo da escola, portanto, de professores, alunos e técnicosadministrativos. Em âmbito nacional isto se traduziu na necessidade de aumentar a interlocução com a Associação Brasileira de Educação Médica (ABEM) que tinha sido vista em muitos momentos quase como um foco de resistência à intensidade das transformações almejadas pela DENEM. Entender aquela associação como importante ator com o qual poderia haver conflitos $e$ contradições mas também um diálogo produtivo foi diferencial na relação entre as duas entidades e no processo histórico da educação médica nesta década.

A partir de 91 ocorre um novo fenômeno de ampliação dos atores envolvidos na problematização do tema. Com a criação da Comissão Interinstitucional Nacional de Avaliação do Ensino Médico (CINAEM) 11 entidades que compõem esta Comissão (dentre elas ABEM, DENEM, Conselhos de Medicina, Associação Nacional dos Docentes do Enino Superior etc) se envolvem intensamente com a questão. Além da comunidade acadêmica, o movimento passa a contar com entidades relacionadas com o trabalho e a prática médica, com a Universidade e com o setor saúde, trazendo mais legitimidade e inumeráveis benefícios para o movimento pela transformação da escola médica.

O movimento se massifica, apesar de contar com um colegiado "diretor" formado pelas 11 entidades. O processo de produção de instrumentos e saberes, formulação de políticas, apontamentos de objetivos $e$ pactuação de compromissos passa a se dar por meio de uma viva construção coletiva em oficinas com a maioria das escolas médicas do país e participação paritária de professores e alunos. 